\title{
Neurologie op het Breukvlak van Twee Eeuwen
}

Citation for published version (APA):

Troost, J. (2001). Neurologie op het Breukvlak van Twee Eeuwen: Afscheidsrede door Prof. dr. J. Troost. Universiteit Maastricht. https://doi.org/10.26481/spe.20011102jt

Document status and date:

Published: 02/11/2001

DOI:

10.26481/spe.20011102jt

Document Version:

Publisher's PDF, also known as Version of record

\section{Please check the document version of this publication:}

- A submitted manuscript is the version of the article upon submission and before peer-review. There can be important differences between the submitted version and the official published version of record.

People interested in the research are advised to contact the author for the final version of the publication, or visit the DOI to the publisher's website.

- The final author version and the galley proof are versions of the publication after peer review.

- The final published version features the final layout of the paper including the volume, issue and page numbers.

Link to publication

\footnotetext{
General rights rights.

- You may freely distribute the URL identifying the publication in the public portal. please follow below link for the End User Agreement:

www.umlib.nl/taverne-license

Take down policy

If you believe that this document breaches copyright please contact us at:

repository@maastrichtuniversity.nl

providing details and we will investigate your claim.
}

Copyright and moral rights for the publications made accessible in the public portal are retained by the authors and/or other copyright owners and it is a condition of accessing publications that users recognise and abide by the legal requirements associated with these

- Users may download and print one copy of any publication from the public portal for the purpose of private study or research.

- You may not further distribute the material or use it for any profit-making activity or commercial gain

If the publication is distributed under the terms of Article $25 \mathrm{fa}$ of the Dutch Copyright Act, indicated by the "Taverne" license above, 


\title{
Neurologie op het \\ Breukvlak van Twee Eeuwen
}

\author{
Rede \\ uitgesproken bij het afscheid \\ van het ambt van Hoogleraar Klinische Neurologie \\ aan de Faculteit der Geneeskunde van de
}

Universiteit Maastricht en het Academisch Ziekenhuis Maastricht

op wrijdag 2 november 2001

door:

Prof. dr. J. Troost 

MUNHEER DE RECTOR MAGNTFICUS, DAMES EN HEREN,

Toen de historicus Jan Romein in zujn opus magnum "Op het Breukvlak van Twee Eeuwen" de geneeskunde behandelde bij de overgang van de $19 \mathrm{e}$ naar de $20 \mathrm{e}$ eeuw, citeerde hij de Duitse medisch-historicus Hemmeter die stelde dat er een snelle vermeerdering was van de kennis in het met exact wettenschappelijk methoden ontdekken van de oorzaken der ziekten en tevens van het op dezelfde rationele wijze vinden van geneesmiddelen daartegen. Dat de enige voorspelling die hij in deze op 24 april 1900 gehouden lezing deed, $\mathrm{nl}$. dat de eerste helft van de twintigste eeuw het kankervraagstuk zal oplossen, niet is uitgekomen, geeft te denken. Het is een citaat, dat in ongeveer dezelfde bewoordingen gehouden kan worden bij de overgang van de $20 \mathrm{e}$ naar de $21 \mathrm{e}$ eeuw, hoewel er nu waarschijnlijk niet gemakkelijk iemand gevonden wordt, die de voorspelling zal herhalen.

Is er dan niets wezenlijks gebeurd de laatste honderd jaar? Zeker, er zijn grote veranderingen opgetreden in de wijze van denken over ziekten, in de diagnostische processen en in het therapeutisch handelen. Toch zijn er niet alleen successen geboekt. Leek het aanvankelijk rond het midden van de vorige eeuw erop, dat het probleem van de infectieziekten oplosbaar was, tegen het einde van de eeuw namen de problemen als gevolg van toenemende resistentie tegen antibacteriële middelen toe en was er een nieuwe dodelijke infectieziekte, HIV, toegevoegd aan de talloze reeds bestaande infecties.

Ik zal, dames en heren, niet proberen de ontwikkeling van de geneeskunde in 45 minuten te behandelen, doch mij beperken tot ontwikkelingen in de neurologie en dan alleen voor de periode die ik zelf heb meegemaakt, van maart 1965 tot heden. 
Toen ik als arts-assistent, het woord AGIO bestond toen nog niet, aan mijn opleiding in de neurologie begon, begon ik aan een wak, dat in zijn werkwijze op vrijwel geen enkel vlak lijkt op de neurologie anno 2001.

En hoewel alles dus anders was, waren er ook problemen, die hetzelfde zijn als nu. Een krantenkop eind mei 1965 in het Utrechts Nieuwsblad luidde: "Professor Sillevis Smitt (het toenmalige hoofd van de Neurologische Kliniek te Utrecht) sluit kliniek voor patienten met schedelverwondingen. Wij staan klaar maar zijn onmachtig te helpen. Oorzaak: tekort aan verpleegsters." U ziet, wat dat betreft is er nu niets nieuws onder de zon.

Opmerkelijk is ook, dat er toen een Neurologische Kliniek was in het Academisch Ziekenhuis. "Thans heeft een Academisch Ziekenhuis een afdeling Neurologie.

Waarin verschilde het vak toen van nu? In de eerste plaats in het tempo. De Utrechtse kliniek had \pm 100 volwassen- en \pm 30 kinderbedden. Bij een patiënt van wie de aard van de ziekte niet duidelijk was, bestond er een indicatie voor opname ter observatie. Een dergelijke opname periode kon meerdere weken duren. Een wijze van werken, die thans ondenkbaar is. In de tweede plaats verliep het diagnostisch proces totaal anders.

Het lichamelijk en neurologisch onderzoek van de patiënt gebeurde veel minutieuzer dan nu. Gelet moest worden op zgn. petits signes die van betekenis konden zijn. Dit was toen ook nodig, aangezien de betrekkelijk patiëntvriendelijke imaging technieken nog niet bestonden. Het aanvullend onderzoek bestond uit een beperkt hematologisch en klinisch-chemisch bloedonderzoek, de "neurologische bezinking", bestaande uit een lumbale punctie en onderzoek van de liquor cerebrospinalis, en klinisch neurofysiologisch onderzoek, te weten EEG, EMG en echografisch onderzoek van de schedel.

Methoden on de hersenen zelf zichtbaar te maken waren er niet. Wel werden twee uiterst barbaarse onderzoekmethoden gebruikt om verplaatsing van 
hersenweefsel zichtbaar te maken, te weten: pneumencephalografie en carotis- en vertebralisangiografie. Voor het eerste onderzoek werd bij de zittende patiënt na aflopen van de liquor een flinke hoeveelheid lucht door de lumbaalnaald ingespoten. Deze luchtbel steeg vervolgens op en wulde het ventrikelsysteem. Vervolgens werden röntgenfoto's van de schedel gemaakt. Uit de contouren van de ventrikels en eventuele verplaatsing daarvan kon je ongeveer de positie van een tumor bepalen.

De angiografie werd in die tijd nog verricht middels een directe punctie van de arteriën in de hals. U kunt zich voorstellen dat, alvorens over te gaan tot deze zeer onaangename handelwijzen, er een zeer goede indicatie voor moest zijn, vandaar het grote belang van een goed lichamelijk onderzoek.

Dé grote ommekeer in het neurologisch diagnostisch proces was de komst van de CT scan, die door veel neurologen in het begin van de jaren 70 voor het eerst werd gezien op het Wereldcongres Neurologie in Barcelona.

De machine heette toen nog EMI scan naar de eerste fabrikant.

Dit veroorzaakte destijds een grote opwinding in de neurologische wereld. Voor het eerst konden de hersenen zelf worden afgebeeld en nog wel op een patiëntvriendelijke wijze. Deze scanners zijn de afgelopen 30 jaar technisch sterk verbeterd, sneller geworden en met een groter oplossend vermogen. De komst van de MRI scanner heeft dit diagnostisch vermogen verder verfijnd. Een ander diagnostisch imaging module vormde de nucleair geneeskundige scanner. Aanvankelijk in de jaren 60 nog een statische scintigrafie waarbij op tamelijk onbeholpen wijze hersentumoren werden aangetoond. De betrouwbaarheid hiervan was matig. Uit een door mij uitgevoerd retrospectief onderzoek bij ruim 600 tumoren werd een betrouwbaarheid van $\pm 85 \%$ gevonden. De nucleaire geneeskunde heeft zich echter ook stormachtig ontwikkeld. Zo kunnen we nu receptoren aantonen in wivo en soms zelfs afzonderlijk de prae- en postsynaptische, iets wat onder meer nu gebruikt wordt bij de evaluatie van de ziekte van Parkinson. 
Wiet alleen middels sterk verbeterde imaging technieken is het diagnostisch proces verbeterd. De mogelijkheden voor chemisch onderzoek van bloed en liquor zijn sterk uitgebreid en verbeterd. Moleculair biologische methoden zijn toegevoegd aan het diagnostisch proces en helpen bijwoorbeeld bij de differentiatie van kankercellen t.o.v. niet maligne cellen zoals o.m. is aangetoond in het proefschrift van Robert van Oostenbrugge.

Een zeer grote aanwinst en met name bij diverse zgn. neurodegeneratieve aandoeningen is de mogelijkheid tot genetisch onderzoek.

Van vele neurologische aandoeningen is inmiddels op DNA niveau de mutatie bekend. Een in de Leidse school gevonden mutatie van het PQ Ca kanal heeft de migraine definitief uit de groep functionele stoornissen gehaald. Nu het menselijk genoom ontrafeld is, zullen vele andere aandoeningen volgen. De gedachte, dat dit ook in de nabije toekomst zal leiden tot verbeterde behandelingen deel ik niet. Deze gedachte heeft namelijk bij veel beleidsmakers en managers postgevat. Dat het ingewikkelder is dan op het eerste gezicht lijkt, moge blijken uit het feit dat het gendefect van de ziekte van Huntington al vele jaren bekend is. Ook het genproduct, huntingtine, is al vele jaren bekend. Toch weten we nog steeds niet wat dit eiwit precies doet, laat staan dat modulatie van dit eiwit een therapeutisch effect zou krijgen. Het "vak" proteonomica, een wan de speerpunten van de Brede Onderzoek Strategie in Maastricht, staat nog in z'n kinderschoenen.

Zo zijn er in de diagnostische fase in de 36 jaar dat ik nu in de neurologie werkzaam ben, talloze essentiële en soms principiële veranderingen opgetreden in de diagnostiek.

Is dan niets hetzelfde gebleven? Jawel, de klachten en aandoeningen van de patiènt die op het spreekuur komt, in de hoop genezing dan wel verlichting wan klachten te krijgen. 
Wat zijn de therapeutische mogelijkheden in de Neurologie?

Robert Currier, editor van het Yearbook of Neurology and Neurosurgery, schreef in 1991 in de introduction van dat jaar: "Neurologic diseases are beginning to respond to research efforts. We are no longer therapeutically bankrupt. It's probable that neurologists do more good than harm. I wasn't sure of that 40 years ago." Dat laatste geldt wat mij betreft ook voor de situatie in 1965 .

Wat waren de therapeutische opties toen? Efficiënt waren de antibiotica voor de bacteriële infecties. Epilepsie kon medicamenteus redelijk behandeld worden. Van de thans eerste keus middelen was alleen Carbamazepine in 1963 geregistreerd. Valproïnezuur kwam pas in 1969 op de markt. Voor de neurodegeneratieve aandoeningen bestond toen geen enkele effectieve behandeling. De ziekte van Parkinson werd met anticholinergica behandeld, met matig tot slecht resultaat. Ik herinner me de fantastische effecten van de intraveneuze toediening van het racemische mengsel dopa, dat mijn toenmalige supervisor Jennekens toediende aan een patiënte met een ernstige vorm van Parkinson. Helaas duurde het effect maar enkele uren. Multipele Sclerose was onbehandelbaar. Om nog eens aan te geven hoever die tijd van de huidige afstaat, moge blijken uit het feit dat wij toen nog strychnine stijgkuren voorschreven als roborerend middel. Ondenkbaar voor de huidige arts-assistenten. Neuromusculaire aandoeningen waren niet behandelbaar.

De ziekten die thans neurochirurgische interventie behoeven, werden ook toen geopereerd. Doordat tumoren door de moderne imaging techmieken eerder worden ontdekt, lijkt de overleving thans langer te zijn. De vraag is of dat werkelijk zo is of dat dit een gevolg is wan de vroegere ontdekking. De idee van andere specialismen dat de neurologie weinig therapeutisch te bieden had, klopte toen met de realiteit. 
Is dit ru veranderd? In mijn beleving heeft de neurologie thans therapeutisch veel te bieden. Dit geldt voor vele ziektebeelden in de neurologie. De cerebrovasculaire aandoeningen, vroeger een aandoening waar met een zeker fatalisme naar werd gekeken, worden thans actief en intensief behandeld. In de eerste plaats door de invoering van zgn. Stroke Units, als gevolg waarvan mortaliteit en morbiditeit met enige tientallen procenten zijn gedaald. In de tweede plaats door de thrombolyse waardoor de behandeling van een CVA een acute zaak is geworden.

In de behandeling van epilepsie kan de neuroloog thans beschikken over een veelvoud van effectieve anti-epileptica. Voor therapieresistente vormen is epilepsiechirurgie en/of nervus vagus stimulatie beschikbaar.

Voor de behandeling van de ziekte van Parkinson is er een therapeutisch arsenaal van dopa preparaten, dopa-agonisten en COMT remmers. Ook hier biedt functionele neurochírurgie soelaas voor die patiënten bij wie de orale medicatie onvoldoende effectief is. Zelfs voor de ziekte van Alzheimer komen de eerste, nog weinig effectieve middelen op de markt.

Multipele Sclerose is een commercieel interessante aandoening geworden met meerdere dure middelen ter behandeling. De plaats van deze middelen geeft nog aanleiding tot veel discussie die deels zelfs op de televisie wordt uitgevochten. Ook in de neuromusculaire hoek komen de eerste behandelingen, deels efficiënt, bijv. gammaglobuline bij de ziekte van GuillainBarré, deels nog weinig effectief, bijv. Rilutek bij de behandeling van amyotrofische lateraalsclerose, ter beschikking. De eerste genetische behandelingsmodaliteiten verschijnen bijv. bij de ziekte van Pompe.

Deze behandeling die in Rotterdam gebeurt, lijkt effectief. Helaas dreigt de leverancier het financied niet te kunnen bolwerken, zodat mogelijk het project een vroege dood sterft. Ik zal niet proberen $U$ in te leiden in alle thans mogelijke neurologische therapieẻn, doch hoop ik met dit korte resumé te hebben aangetoond dat een neuroloog nu een echte dokter is. 
Hoe is de afdeling Neurologie wan het azM gevaren tijdens deze ontwikkelingen? De afdeling is untgegroeid tot een volwaardige academische afdeling. Ze wordt thans bemand door 13 medisch specialisten, 12 artsassistenten waarvan 10 in opleiding, eén arts die het onderzoek ondersteunt en dit najaar een opleiding tot klinisch-epidemiolloog afrondt, en een wisselend aantal arts-onderzoekers en AIO's.

De afdeling, ik ook dus, heeft bewust gekozen om de neurologie in den brede te behandelen, inclusief het onderzoek. Deze keus staat enigszins haaks op het Maastrichtse model dat propageert om 1 à 2 onderwerpen te nemen en die in de diepte in een onderzoeksinstituut te bestuderen.

Ik heb het altijd jammer gevonden om delen Neurologie te laten vallen.

We hebben natuurlijk wel speerpunten. Allereerst cerebrovasculaire aandoeningen, waar onder de bezielende leiding en coaching van Jan Lodder een groot aantal promoties plaatswonden. Was dit onderzoek aanvankelijk voornamelijk epidemiologisch gericht, de laatste jaren wordt hier, mede ook door de komst van Robert van Oostenbrugge basaal neuroscience onderzoek verricht. Tevens loopt er een grote internationale triall, bedacht en uitgevoerd vanuit Maastricht, de EGASIS trial, met als doel na te gaan of vroegtijdige GABA-erge stimulatie protectief is in de behandeling van CVA's.

Tezamen met de afdeling Medische Informatica hebben wij een elektronisch patiëntendossier voor CVA patiënten ontwikkeld, dat redelijk tot goed voldeed. Toch blijkt dan dat de automatisering in de ziekenhuizen, ook azM, nog niet zover is dat een dergelijk project ingebed kan worden in het ziekenhuis netwerk. Ook kan het ziekenhuis dan niet die steun bieden die nodig is voor een echte implementatie in de patiëntenzorg. Een tweede lijn van onderzoek vindt zijn weg in de Neuro-oncologie met Albert Twijnstra als trekker. Ook hier vindt met name onderzoek plaats op moleculain celniveau. Wim Weber zorgt hier voor extra versterking. Mark de Krom heeft zijn niche in de epilepsie gevonden, maar geeft telkens weer blijk van uiterst praktisch onderzoek. 
Zo is onder zijn leiding in een trial vastgesteld dat bedrust geen meerwaarde heeft in de behandeling van hemia nuclei pulposi. Hoewel deze constatering nogal eenvoudig lijkt, was het toch een revolutionaire omikering in de behandeling van dexe patiêntengroep. Raymond Hupperts is na een sabbatical year ter nadere bestudering van Multipele Sclerose in resp. Vancouver en Cambridge, bezig in snel tempo een MS centrum op te zetten.

Hij heeft inmiddels ondersteuning van 1 arts-assistent, 1 MS verpleegkundige en 1 secretaresse, terwijl de plannen bestaan dit gefaseerd uit te bouwen. Chris Höweler heeft de afgelopen jaren zijn batanbrekend werk op het gebied van myotone dystrofie gecontinueerd en heeft nu de hulp van Karin Faber, die binnenkort in Nederland geregistreerd zal worden als eerste neuromyoloog.

Het werk van Marc De Baets betreffende immunologische aspecten wan experimentele myasthenia gravis is inmiddels geheel ingebed in de afdeling Neurologie. Fred Vreeling koestert zijn oude liefde, de ziekte van Parkinson, en is nauw betrokken bij de deep brain stimulation ter behandeling hiervan, samen met Veerle Vandewalle, neurochirurg, en Vivianne van KranenMastenbroek, klinisch neurofysiologe.

En dan mijn oude liefde, de kinderneurologie. Deze is onder de bezielende leiding van Hans Vles, ondersteund door Biene Weber en sinds een jaar Edgardo Maza, uitgegroeid tot een afdeling met een grote hoeveelheid patiẻntenzorg. Ook het onderzoek, deels klimisch, deels basaal, neemt steeds grotere vormen aan. Binnen nu en een jaar zullen zeker 3 promoties op dit gebied plaatsvinden. Gezien de breedte van het interessegebied zal het $\mathrm{U}$ dan ook niet verbazen, dat het onderzoek van de afdeling plaatsvindt in meerdere onderzoeksinstituten, te weten: Hersenen \& Gedrag, CARIM, GROW, ExTra en een beetje Nutrim.

Voor wat het onderwijs betreft participeert de afdeling in een aantal blokken, terwijl én blok een geheel neurologische inhoud heeft.

De afdeling heeft een eigen keuzeblok Klinische Neurologie en participeert 
in het keuzeblok Niet-klimische Neurowetenschappen. Het co-assistentschap Neurologie wordt door de studenten steeds als goed beoordeeld, zowel in het azM als in de geaffilieerde ziekenhüzen. Gijs van Hellemondt heeft inmiddels voor het skillslab m.n. ten behoeve van $4 \mathrm{e}$ jaars medische studenten een geheel nieuwe fraaie videoband wan het neurologisch onderzoek gemaakt, die zal worden omgezet in een interactieve CD-ROM.

Het met veel gejuich geintroduceerde nieuwe curriculum baart ons grote zorgen. Ten eerste, doordat in de resterende twee theoretische jaren slechts weinig neurologie gegeven kan worden, waarbij dan ook nog een deel van de tijd besteed moet worden aan basisvorming van neuro-anatomie en -fysiologie. Ten tweede doordat in het $3 \mathrm{e}$ jaar grote groepen studenten de kliniek in moeten. Wij zijn daar ruimtelijk niet voor geêquipeerd, terwijl ook het aantal docenten-uren zodanig groot is, dat dit niet door de huidige staf gegeven kan worden, tenzij ten koste van onderzoek, hetgeen de motivatie niet ten goede komt.

Ten laatste door de nieuwe constructie van de co-schappen waar als gevolg van een zgn. "voor en na-week" de onderwijsbelasting zodanig toeneemt alsook het beslag op de niet aanwezige ruimte, dat wij gemeend hebben de onderwijsdirecteur te moeten zeggen, dat dit voor ons niet uitvoerbaar is. Ook de verkorting van 6 naar 4 weken actief patiëntencontact voor de medische student is voor ons onaanvaardbaar.

Tenslotte de patiëntenzorg. Steeds vaker lees je artikelen in de krant met als inhoud: Onnodige bureaucratie houdt steeds meer artsen en verpleegkundigen van hun werk. Managers hebben de macht in de zorg overgenomen. Management heeft meer status, maar het echte werk is mensen beter maken. P. Lems, senior consultant bij Prismant, het grootste adviesbureau in de zorg. spreekt van een nieuwe kaste. Managers moeten worden aangepakt om de zorg weer vitaal te krijgen, vindt Lems. De macht moet terug naar de professionals (bron: De Volkskrant, 25 september 2001). 
Hoe is dit in het azM? Hoewel de voorzitter van de Raad van Bestuur de stelling verdedigt dat het aantal managers is afgenomen, is de beleving van een forse toename van de bureaucratie alleen maar toegenomen. Hoe je hier op moet inspelen is niet duidelijk. Het zall wel uitdraaien op een manager die de bureaucratie moet bestrijden. Of dit helpt, valt te betwijfelen.

\section{Hoe functioneert de Neurologie onder deze voorwaarden?}

Poliklinisch is het aantal eerste werwijzingen de afgelopen 10 jaar ongeveer verdubbeld. Doordat ook de polikliniek Neurochirurgie in dezelfde ruimte werd gehuisvest, werd de poli te klein. Het afgelopen jaar hebben wij met steun van de Rad van Bestuur een majeure verbouwing kunnen uitvoeren, waardoor de bestaande ruimte efficiènter kon worden ingedeeld. Hoewel dit duidelijk verlichting heeft gegeven, zijn niet alle problemen opgelost.

Het vak vraagt thans naast de gewone open spreekuren een verdere differentiatie; dit betekent dat er specifieke spreekuren zouden moeten zijn voor $0 . \mathrm{m}$. epilepsie, oncologie, neuromusculaire aandoeningen, TIA-poli, kinderpoli, om slechts enkele te moemen.

Dit is niet alleen nodig voor een goede patiëntenlogistiek, maar heeft ook een duidelijke meerwaarde voor de opleiding van arts-assistenten. Visitatierapporten eisen zelfs een participatie van arts-assistenten bij dit soort superspecialistische poli's. Hiervoor is de ruimte nog onvoldoende. Hoewel second opinions door beleidsmakers vaak worden gezien als topreferente of topklinische zorg is het in de praktijk vaak een veel tijd consumerende belasting, waarvan de meerwaarde in vele gevallen betwijfeld kan worden.

De klinische afdeling Neurologie is in de loop der jaren steeds kleiner geworden. Dit wordt voor een deel veroorzaakt door de moderne diagnostische technieken, die veelal poliklinisch kunnen gebeuren. Opgenomen worden nog slechts die patiënten die veel zorg nodig hebben zoals CVA patiènten, oncologische patiènten, traumata en enkele encephalitiden. 
De afdeling beschikt ower een goed geonganiseerde Medium Care, die tevens als Stroke Unit wordt gebruikt. Door de ontwikkeling van het Transmurale Maastrichtse CVA project, dat werd ontwikkeld in samenwerking met het Transmuraal Diagnostisch Centrum, de capaciteitsgroep Huisartsgeneeskunde, vertegenwoordigers van de verpleegklinieken en de thuiszorg, alsmede de afdeling Revalidatiegeneeskunde, lukt het ons de doorstroming van deze patiëntencategorie zodanig te organiseren, dat de gemiddelde opnameduur is teruggebracht tot tien dagen. Gelukkig zijn wij ook met een goed uitgeruste registratiekamer op de afdeling, waardoor wij video-EEG registraties kunnen uitvoeren, zowel voor diagnostische doeleinden als voor epilepsiechirurgie. Een goede samenwerking met de afdeling Neurochirurgie en Klinische Neurofysiologie is hiervoor essentieel.

In de opleiding van arts-assistenten is in de loop der jaren een duidelijke verbetering opgetreden. Bij mijn komst in 1992 beschikte de afdeling over vier opleidingsplaatsen. In de loop der jaren is dit gelukkig gestadig gegroeid tot tien. Dit komt de kwaliteit van patiëntenzorg duidelijk ten goede, evenals het opleidingsklimaat.

De arts-assistenten worden actief betrokken bij onderzoekprogramma's van de afdeling. Dit heeft er toe geleid dat alle assistenten, met uitzondering van één, na hun registratie tot neuroloog het azM gepromoveerd hebben verlaten. Deze actieve participatie blijkt ook uit het feit dat de afdeling alle jaren een of meer genomineerden had voor de Pélerinprijjs, die jaarlijks door het azM wordt uitgekeerd voor het beste onderzoek verricht door een $\mathrm{AGIO}$.

Wat zijn de verwachtingen voor de toekomst? Met zekerbeid valt hier niets over te zeggen, mede aangezien het nog onduidelijk is wie mijn opvolger wordt, die hierin zeker medebepalend zal zijn. Voor een deel zal het ook afhangen van externe factoren. De huidige dreigende recessie $z$ al de hoeveelheid beschikbare middelen voor de zorg mogelijk in negatieve zin beinvloeden. Toch durf ik een aantal voorspellingen wel te maken, hoewel, 
zoals Wim Kan zei, voorspellen moeilijk is, zeker als het de toekomst betreft. In de eerste plaats verwacht ik, dat het CVA onderzoek gecontinueerd zal worden en dat dit meer richting basiswetenschappen zal gaan. De neuro-oncologie zal in volume toenemen waardoor mogelijkheden voor research groter worden. Het MS centrum zal zeker groeien en onderzoek genereren. Het onderzoek naar neuromusculaire ziekten zal toenemen.

De functionele neurochirurgie zal zeker de komende jaren in omvang toenemen. Ook de kinderneurologie zal, zoals kinderen eigen is, groeien. Uit mijn opsomming moge blijken, dames en heren, dat de afdeling neurologie in Maastricht een bloeiende afdeling is.

Ik verkeer in een wat wonderlijke situatie. Vandaag neem ik afscheid van de Neurologie, een vak dat ik al die jaren met veel plezier heb uitgeoefend. Reeds vroeg in mijn studententijd wist ik dat ik dit wilde en een andere keuze heb ik ook nooit overwogen. Het vak ontwikkelt zich momenteel zeer snel, mede als gevolg van het in Amerika zeer succesvolle project: The Decade of the Brain.

Hoewel de patiêntenzorg voor mij al gestopt is, zal ik deze ontwikkelingen de komende tijd nog met belangstelling volgen in mijn functie als wetenschappelijk directeur van het instituut Hersenen \& Gedrag, hetgeen nog tot 1 oktober 2003 duurt. Dit maakt dat dit een soort van deelafscheid is.

Dan kom ik nu, mijnheer de Rector, toe aan mijn dankwoord.

In de eerste plaats dank ik het College van Bestuur voor het feit, dat zij mij het vertrouwen hebben gegeven om deze functie uit te oefenen.

De contacten die ik met $U$ had waren steeds constructief.

Ik dank het Bestuur van de Faculteit der Geneeskunde. In de ruim negen jaar dat ik nu in Maastricht ben, heb ik vier decanen meegemaakt en drie directeuren. Het contact is in de laatste jaren intensiever en inhoudelijk 
duidelijker, deels als gevolg van mijn positie als instituutsdirecteur: De discussies zijn open en plezierig.

Ik dank de Raad van Bestuur van het azM. In de zes jaren dat ik voorzitter van het Stafconventsbestuur was, heb ik veel en vaak intensief contact met U gehad. Dit verliep altijd op de meest plezierige wijze.

Ook bij moeilijke zaken kon er open overleg plaatsvinden. Ook vanuit mijn rol als voorzitter van het Bestuur van BZe V had ik frequent contact en ook daar was er steeds goed overleg. Ik heb de contacten met $U$ dan ook altijd. als uiterst plezierig, constructief en zinnig gevonden. Dit ondanks mijn soms wat kritische kanttekeningen managers betreffende.

Ik dank het management van BZe $\mathrm{V}$ voor een jarenlange samenwerking. In eerste instantie met Hans Fiolet en Herman Dewalque.

Met name met Hans heb ik in heel wat brainstorm sessies de meest fantastische ideeën, mogelijk en onmogelijk, kunnen maken. De samenwerking met Gerhard Vermaeten en sinds kort Roy Lalisang, heb ik bijzonder op prijs gesteld. In de zes jaren die ik heb mogen participeren in het BZe management, bleek telkens weer hoe moeilijk een echt decentraal beleid te realiseren is. Regelmatig botsen de belangen van de centrale en decentrale organisatie. Verwonderlijk is dit niet, aangezien een totale autonomie van de decentrale delen aanleiding zou geven tot de vorming van zes ziekenhuisjes in éên gebouw.

De collegae neurologen dank ik allen in de eerste plaats voor het feit. dát jullie mij geaccepteerd hebben als afdelingshoofd c.q. capaciteitsgroepvoorzitter, en in de tweede plaats dat wij gezamenlijk de afgelopen jaren de afdeling hebben kunnen uitbouwen tot wat her nu is.

En last but not least dank ik jullie voor de vriendschap die ik heb mogen ervaren. 
Ik dank de collegae van de afdelingen Neurochirurgie en Klinische Neurofysiologie voor de prettige samenwerking.

Tevens dank ik de medewerkers van het secretariaat, de polikliniek en de verpleging voor de samenwerking.

In het bijzonder dank ik Thera van Lieshout, mijn steun en toeverlaat in het administratieve oerwoud van faculteit en ziekenhusis. De bureaucratie van het ziekenhuis eist nu, dat ik met bonnetjes moet aantonen, dat zij doet, wat ze doet. Vroeger bestond er een zeker vertrouwen in de medewerkers in de organisatie, nu hebben we human resource management en andere treurig stemmende termen uit het jargon van de kaste der managers, voorwaar geen verbetering.

Tenslotte dank ik mijn kinderen en hun partners, met name voor hun steun in moeilijke tijden.

Ik heb gezegd! 